\title{
TECTONICS OF THE POKROVO-KIREEVAN ORE CLUSTER OF THE NEAR-AZOVIAN
}

\author{
N.N. Shatalov \\ (Recommended by doctor of geological-mineralogical sciences L.S. Galetsky)
}

Institute of Geological Sciences of NAS of Ukraine, Kiev, Ukraine, E-mail: geoj@bigmir.net Doctor of geological sciences, senior scientific worker.

The results of investigations for the large structural Pokrovo-Kireevskaya ore knot within the of Donbas and Near-Azovian megablock of the Ukrainian Shield are presented. The features of fault-block tectonics and its influence on forming the ore knot are defined. The Kalmius, Hruzsko-Elanchik, Yuzhno-Donetsk, and other fault zones of the orthogonal and diagonal systems and their significance in the localization of unique fluorite rare-earth deposit are characterized, by using satellite images and geological-geophysical data. The features of magmatism manifestation are studied.

Key words: tectonics, fault geostructure, geoblock, dikes, fluorite-rare metals ore deposit.

\section{TЕКТОНІКА ПОКРОВО-КИРЕЇВСЬКОГО РУАОНОСНОГО ВУЗАА ПРИАЗОВ'Я}

\author{
М.М. Шаталов \\ (Рекомендовано д-ром геол.-мінерал. наук Л.С. Галецьким)
}

Інститут геологічних наук НАН Украӥни, Київ, Україна, E-mail: geoj@bigmir.net Доктор геологічних наук, старший науковий співробітник.

Наведені результати досліджень великого структурного Покрово-Киреївського рудоносного вузла, розташованого в межах зони зчленування Донбасу з Приазовським мегаблоком Українського щита. Визначені закономірності розломно-блокової тектоніки та її роль у формуванні рудного вузла. За аерокосмічними і геолого-геофізичними даними охарактеризовані Кальміуська, Грузько-Єланчицька, Південно-Донецька та інші розломні зони ортогональної та діагональної систем і їх значення в локалізації унікального флюорит-рідкісноземельного родовища. Досліджені особливості прояву магматизму.

Ключові слова: тектоніка, розломна геоструктура, геоблоки, дайки, флюорит-редкіснометалеве родовище.

\section{ТЕКТОНИКА ПОКРОВО-КИРЕЕВСКОГО РУАОНОСНОГО УЗАА ПРИАЗОВЬЯ}

\author{
Н.Н. Шаталов \\ (Рекомендовано д-ром геол.-минерал. наук Л.С. Галецким)
}

Институт геологических наук НАН Украинь, Киев, Украина, E-mail: geoj@bigmir.net Доктор геологических наук, старший научный сотрудник.

Приведены результаты исследования крупного Покрово-Киреевского рудоносного узла, расположенного в зоне сочленения Донбасса с Приазовским мегаблоком Украинского щита. Определены закономерности разломно-блоковой тектоники и ее роль в формировании рудного узла. По аэрокосмическим и геолого-геофизическим данным охарактеризованы

(๖) N.N. Shatalov, 2016 
Кальмиусская, Грузско-Еланчикская, Южно-Донецкая и другие разломные зоны ортогональной и диагональной систем и их значение в локализации уникального флюорит-редкоземельного месторождения. Исследованы особенности проявленного магматизма.

Ключевые слова: тектоника, разломная геоструктура, геоблоки, дайки, флюорит-редкоземельное месторождение.

\section{Introduction}

The problem of Pokrovo-Kireevo structure tectonics is essential due to discovery of the rather large so named deposit of fluorite - rare earth ores within the this structure at the shallow depths. Presently there are known more hundred all-aged fluorite deposits, which are occurred at the different geological formations. The unique Pokrovo-Kireevo fluorite - rare earth deposit was discovered by the geologists from the Near-Azovian Geological Survey Expedition in late the 1950-s in the largest mining district, the eastern Ukraine [Древин и др., 1960]. This deposit represents the demonstrative example of the ore formation at the comparatively shallow depths and in the extremely complicated structure - tectonic knot. By its genetic features the Pokrovo-Kireevo deposit is unique does not have analogues in Ukraine. Ores of similar type are exposed only at the Voznesenka fluorite deposit, the Russian Far East.

\section{The tectonic position of the Pokrovo-Kireevo ore cluster}

The Pokrovo-Kireevo fluorite-rare earth deposit is localized within the boundaries of a very complicated structure - ore knot. In the tectonic context it is situated in the conjunction zone between the rather young "Phanerozoic" Donetsk fold basin and the ancient "Precambrian" Near-Priazovian mega-block of the Ukrainian Shield (USh). In the Precambrian crystalline basement of the region under the sedimentary cover the dome-shaped structure of the same name at the size of $30 \mathrm{~km}$ is suspected to be identify. It composes of gneiss migmatite formations from the Achaean and Proterozoic, as well as granites of the ester Near-Azonian complex from the Neoproterozoic. Here the massifs, stocks, and dykes of multi-aged Phanerozoic rocks of ultrabasic, basic, and alkali compositions are widespread. The segments of the separate arcuate fault, dykes, and other elements of the PokrovoKireevo dome structure are revealed using geophysical and aerospace data [Быстревская, Шаталов, 1980].
The critical elements of tectonics for the study region are the faults [Бондарчук, 1966; Майданович, 1968; Собакарь 1961; Чебаненко и др., 1991]. They are responsible for all heterogeneity and patchiness of the PokrovoKireevo structure, block character for the Eastern Near-Azovian mega-block of the USh and conjunction zone with the Donbas. The rupture dislocations in the region differ in the direction, depth, extension, displacement amplitude both vertically and laterally as well as the other kinematic features. In the south-eastern Ukraine they form the orthogonal and diagonal systems, which consist of the series of subparallel zones dissecting the above mentioned structural stages into the different-sized geoblocks. Most faults emerged in the Precambrian and continue to develop until now. Many zones of rupture dislocations have all typical characteristics of depth faults.

The South-Donetsk fault dividing the NearAzovian mega-block of the USh from the folded Donbas is the structural type of marginal suture, in fact a mini-rift. The plunge of crystalline basement rocks occurred along this fault to the great depths and thick mass of sedimentary and volcanogenic Paleozoic rocks. Deep seismic sounding data clearly defined the SouthDonetsk fault in the relief of the Moho discontinuity and, likely, which penetrates at least to the depth of $200 \mathrm{~km}$. One of the main evidences of its deep-seated disposition is the manifestation here magmatic rock with ultrabasic, basic, and alkali compositions. The South-Donetsk fault leads to tectonic discordance of rock from the "white" Devonian with the Carboniferous sediments and further the crystalline Precambrian rocks with the different horizons of the Devonian period. Along this deep fault (a width of about $10 \mathrm{~km}$ ) it may be directly observed the tectonic relationship among the Precambrian, Hercynian, and Alpine structural stages. The amplitudes of vertical offsets along this fault within the boundaries of "mini-rift" get at a value of $500 \mathrm{~m}$ [Лебедев, Собакарь, 1961; Майданович, 1968; Собакарь, 1961; Чебаненко и др., 
1991]. In the basin of the Mokra Volnovakha River the large - scale faults of north-eastern (Kalmius fault) and submeridional (HruzskoElanchik fault) strikes. They dissect the SouthDonetsk fault and sublatitudinal structures of the folded Donbas. These tectonic dislocations are also characterized by the deep-seated spread features. As far as the tectonic significance, geo-dynamics and magmatism factors, as well as mineralogical, geological and geophysical aspects the Hruzcko-Elanchik deepseated fault is very important in the formation of the rather complicated Pokrovo-Kireevo structural ore cluster. This tectonic zone here is chief among the transverse faults and is no doubt ore controlling structure within the boundaries of the Pokrovo-Kireevo one (laterally and at a depth). The ore occurrence discovered here is exactly coincides with it. That period of the Earth evolution was probably marked by a cracking and stretching of rather thick, dense, and solid - crystalline Earth's crust of the Near-Azovian mega-block in the conjunction of the South-Donetsk and Hruzsko- Elanchik deep-seated fault zones. Strengthening the tectonic and magmatic processes provoked the most magmatic intrusions of alkali-ultrabasic rocks and fluorite-rare earth ore occurrence was formed here.

It is important to point out that the fault within the conjunction zone between the Donbas and Near-Azovian area are classified by the cinematic attributes as follows: strikeslips, oblique-slip faults, thrusts, and transpressional faults. The fault amplitudes here reach to $1-2 \mathrm{~km}$, and total amplitudes of the longitudinal and transverse oblique-slip and transpressional faults along the SouthDonetsk one are about 4-5 km [Майданович, 1968; Собакарь, 1961; Чебаненко и др., 1991]. These rupture dislocations define the complicated fault-block structure of the region. Here there are positive and negative structures such as horsts and grabens, respectively. Embedding the horst-graben structures for the conjunction zone between the Donbas and Near-Azovian mega-block of the USh arose in the Early Frasnian period. The tectonic movements here emerged clearly after the formation of sedimentary rocks of the Nikolaevska suite (Middle Devonian). The change of tectonic condition in the South-Donetsk "micro-avlakogene" was intimately connected with the be- ginning of volcanic activity caused the formation of volcanics of the Petrovsky thickness concealed under effusive and volcanoclastic buildups from the Anton-Taramsk, Dolgan and Razdolnoe Formations.

As far as morphology of the region, this is the flat open landscape (steppe) at the SouthEastern Ukraine. However, here between the rivers Kalmius and Hruzsky Elanchik in the deep fault intersection zone of the diagonal and orthogonal systems A.Ya. Drevin et al. [Древин и др., 1960] have found that the Precambrian crystal base of the Near-Azovian mega-block of the USh penetrated deeply into the range of folding Paleozoic rocks of the Donbas forms the large Elanchik horst (Fig. 1). The horst is bounded by the Voikov thrust (or the Komsomolsky strike-slip by A.P. Rotai) in the west and the Hruzsko-Elanchik strike-slip (the Elanchik-Rovenky fault by I.A. Maidanovich) in the east. The Mesozoic (locally) and Tertiary deposits are sheetlike and near horizontal at the moderate thickness and underlay in this horst forming the top structural

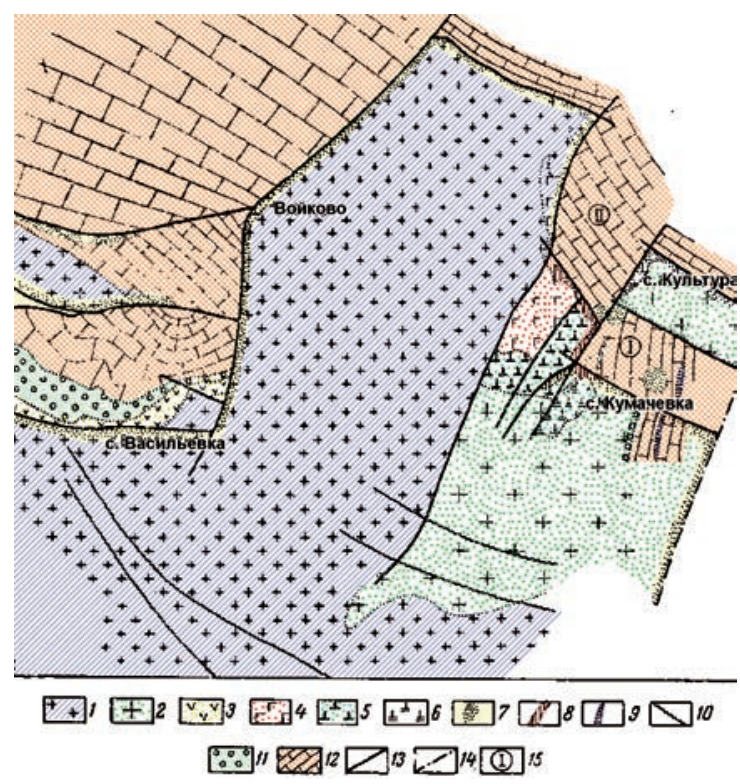

Fig. 1. Scheme of fault-block framework for the Pokrovo-Kireevo structure [Древин и др., 1960]

1 - Archean gneisses and migmatites; 2 - Proterozoic granosyenites; 3 - Upper Divonian basalts; 4 - augite pyroxenites; 5 - alkaline basaltoids and porphyrites; 6 - malignites; 7 - basaltoids under Paleozoic sedimentary rocks; 8 - orthophyres; 9 - andesites and trachyandesites; 10 - dykes of grorudites; 11 - Devonian sedimentary rocks; 12 - Carboniferous sedimentary rocks; 13 - detected faults; 14 - assumed faults according to geophysical data; 15 - grabens 
stage. In contrary, thick volcanogenic sediments from the Devonian, Carbon, and MezoCenozoic revealed by the multiple coring wells are developed in the grabens adjacent to the horst. The depth geological mapping identified the Paleozoic volcanogenic sediments over the Precambrian rocks occur discordantly in the grabens and different buried parts of the Elanchik horst as well as within the geoblocks framing it. These Paleozoic volcanogenic sediments form the middle structural stage. The low horst in the vicinity of the Kultura village is adjacent to the Elanchik one in the east and is detach from it by sub-latitudinal and submeridian grabens.

The bottom (Precambrian) structural stage consists of the ancient Archaean - Proterozoic crystalline rocks, which are represented by gneisses, migmatites, granites, granosyenites, etc. The Precambrian rock outcrops of the Elanchik horst may be observed only along the Hruzsky Elanchik River (between the villages of Kuznetsovo-Mikhailovskoe and Kumachovka) and its right binnacle (the Kamenka draw and others). The erosion processes at this area uncovered grey and rose gneiss - migmatite facies from the Archaean and Palaeoproterozoic as well as the massifs of granosyenites from the Neoproterozoic composed the base of the bottom structural stage. Gneisses, migmatite, and granosyenites within the bounders of the Pokrovo-Kireevo structure are cut by the massifs of pyroxenites, the stocks of basalts, porphyrites, malignites, bostonites and numerous Paleozoic dykes of basic (diabases), acid (orthophyres and quartz porphyries) and alkali (grorudites) compositions. Here there are the localities of cataclasis, myIonitization, and strong alkalization of the host rocks. They are previously determined and characterized by the author as incorporated in the Kuznetsovo-Mikhailovsky dyke belt [Шаталов, 1981, 1986].

The Fig. 1 shows the key features of the Pokrovo-Kireevo structure, which are caused by horst-graben type of the structure of the Earth crust. The large Elanchik horst is bounded to the west, north and east by the smaller horsts and grabens. Their sizes are from $23 \mathrm{~km}$ to $510 \mathrm{~km}$. They are separated from each other by the fault complexes (strikeslips, oblique-slip faults, thrusts, and transpressional faults) with the submeridional and sublatitudinal orientations. Most of them are traced by the coring wells. The most studied among them is sublatitudinal strike-slip extended through the north edge of Kumachovka village. The Neoproterozoic granosyenites and Paleozoic malignites are adjacent to the south fault limb. The amplitude of vertical shift for this fault reaches here to $300 \mathrm{~m}$ [Древин и др., 1960; Майданович, 1968]. The second sublatitudinal fault - slip conjugates with the former and has been mapping to the south from Kultura village. These faults are cut by the Hruzsko-Elanchik fault - slip spreading along the River Hruzsky Elanchik to the west of the villages of Kultura and Kumachievka. This fault zone is traced at the distance of $10 \mathrm{~km}$ and has NE $30^{\circ}$ strike and steep south-east dip. The system of horsts and grabens in the east is bounded by the other fault - slip of the northeastern strike (Fig. 1). The grabens of the Pokrovo-Kireevo structure are filled by the Carboniferous limestones and Jurassic tuffaceous deposits and the Precambrian rocks of horsts (for example, the horst at Kultura village) are only overlapped by sedimentary rocks from the Cretaceous, Palleogene, and Neogene (Fig. 2).

A follow-up study of the conjunction zone between the Donbas and Near-Azovian by the geologists from the Artemivsk and Near-Azovian prospecting expeditions the horst-graben character of the Pokrovo-Kireevo structure is specified and detailed considerably. The pattern of the complex block structure of the Precambrian and Hercynian structural stages for the Pokrovo-Kireevo ore cluster (Fig. 3) is also defined. The new systems of fault- slips and fault-thrusts were mapped here and the large amplitudes of the horizontal and vertical shifts of geoblocks (more $1 \mathrm{~km}$ ) and the character of evolution for the Phanerozoic volcanism are determined [Бутурлинов, Скаржинский, 1970; Майданович, 1968]. In particular, the occurrence fields for sedimentary-volcanogenic rocks of the Paleozoic age and their relationship with fault-block structure were identified. Among volcanic rocks of the Pokrovo-Kireevo structure the rock series of ultrabasic, basic, alkali-subalkaline, and shonkinite - monzonite sets such as augitophyric basalts, augitic pyroxenites, porphyrites, malignites, shonkinites, bostonites, lamprophyres, orthophyres, grorudites and many others [Бутурлинов, Скаржинский, 1970]. 


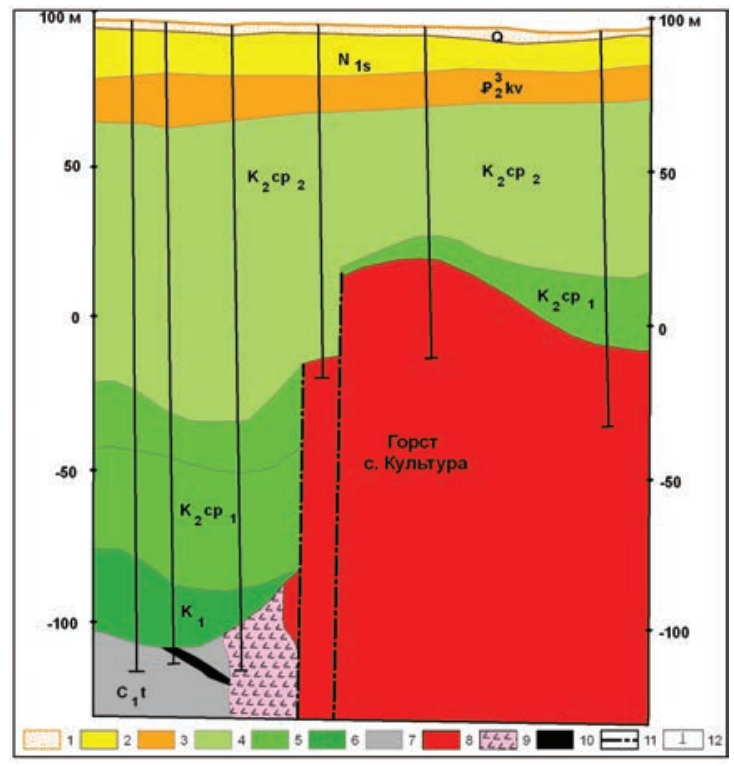

Fig. 2. Geological cross-section of sedimentary cover developed over e system of horsts and grabens from the Pokrovo-Kireevo structure governing fluorite-rare earth deposit. It is composed by the author using geological survey data from the Artemivsk prospecting expedition (V.A. Matiushonok, I.A. Maidanovich, 1970)

1 - anthropogenic sediments (sands, loams); 2 - sediments from the Sarmatian stage of the Neogene (clays, sands, marls); 3 - Upper Eocene sediments, Kiev suite (marls, clays, sandstones); 4 - Upper Cretaceous sediments, Maastrichtian stage (limestones, green sands); 5 - Upper Cretaceous sediments, Campanian stage (bone chert, sands, loamstones); 6 - Lower Cretaceous sediments (kaolinitic clay, sandstones); 7 - sediments of the Tournaisian stage, Carboniferous (dolomite limestones, argillaceous slates); 8 - Precambrian geoblocks; 9 - dyke of Paleozoic age; 10 - fluorite - rare metal occurrence; 11 - faults; 12 - wells

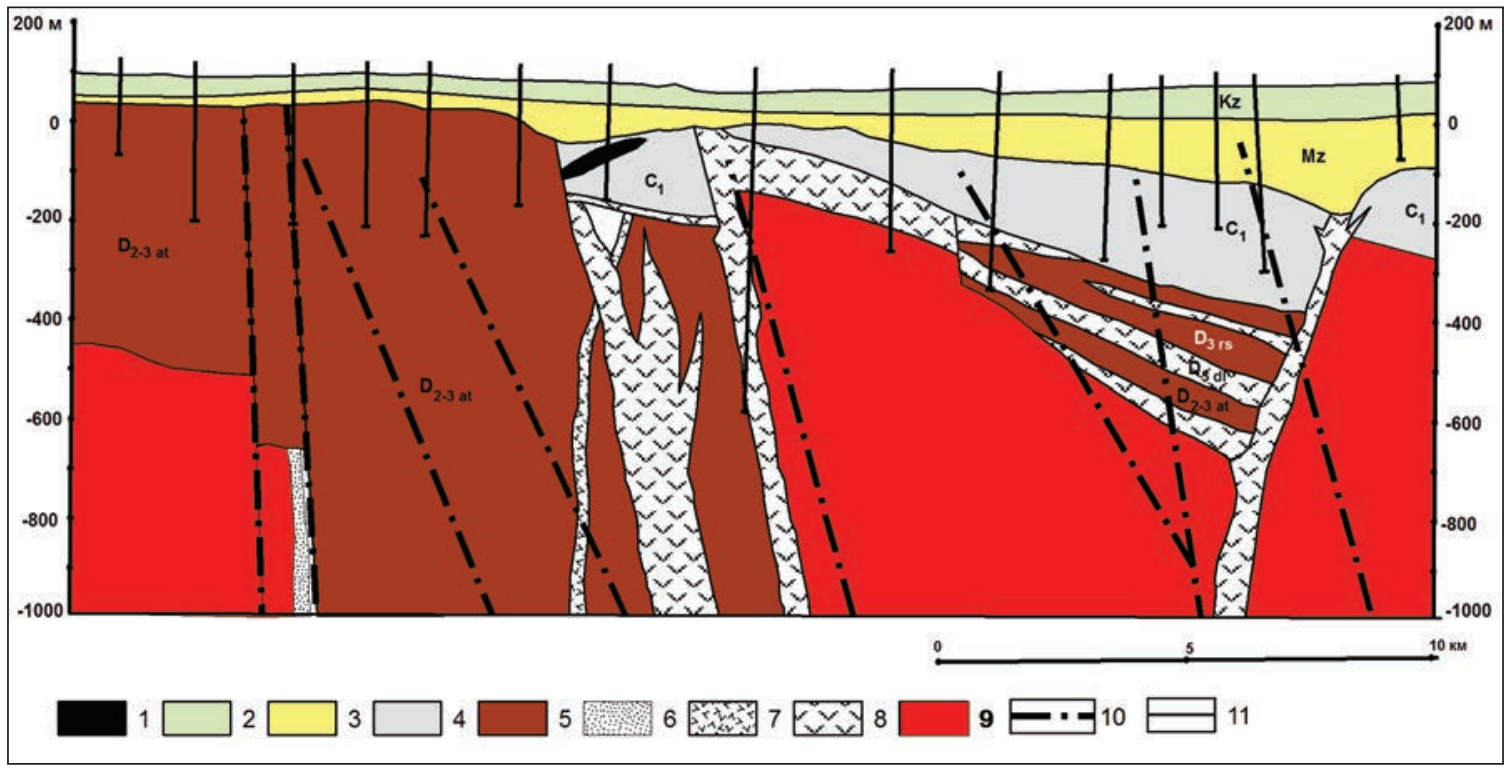

Fig. 3. Geological cross-section shows the "keyboard pattern" of geoblock framework at the PokrovoKireevo fluorite - rare earth deposit. This is composed by the author on a basis of geological survey data from the Artemivsk prospecting expedition (I.A. Maidanovich, N.F. Rusakov, 1970)

1 - fluorite deposit; 2 - anthropogenic sediments; 3 - Mesozoic sediments; 4 - Carboniferous sediments; 5 - igneoussedimentary rocks of the Devonian (Anton-Taramska, Dolhinska and Razdolnenska suites); 6 - mafic dykes of the Precambrian; 7 - dykes of the Devonian age (augitites, limburgites, etc.); 8 - intrusions of the Paleozoic; 9 - geoblocks of the Precambrian basement; 10 fault zones; 11 - wells

It is found that the effusive-terrigene strata from the Late and Early Devonian (Razdolnenska and Dolhinska suites, respectively) as well as effusive stratum from the Middle Early Devonian (Anton-Taramska suite) are here deposited from up to down over the Precambrian geoblocks. In addition to the Paleozoic and Mesozoic dykes (andesites, andesite porphyrites, etc.) cutting the Precambrian and Paleozoic rocks are widespread here. Figs. 3 and 4 perfectly illustrated the character of relations between the Precambrian and Phanerozoic rocks from the Pokrovo-Kireevo horst-graben structure and the features of geological framework and volcanism of the study region. 


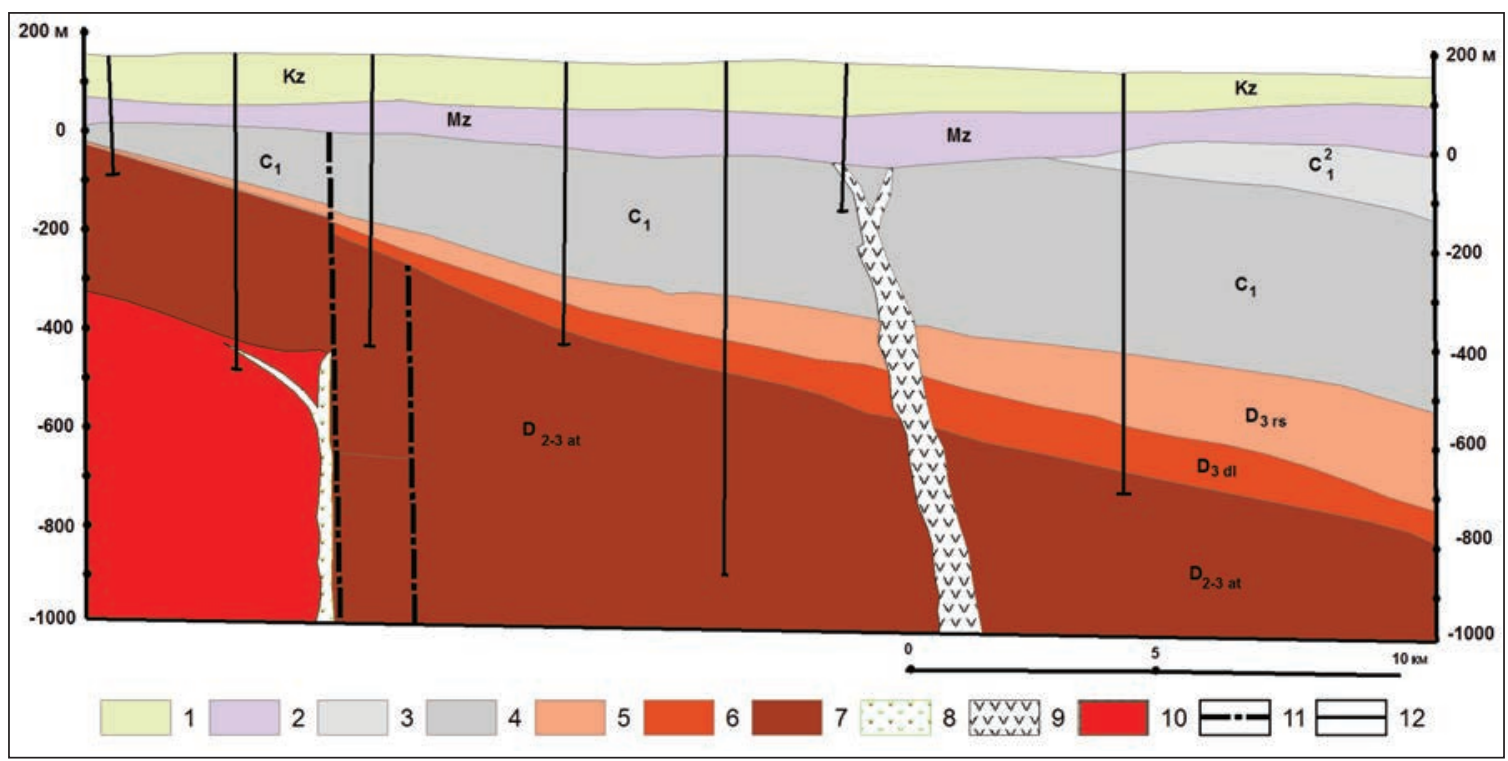

Fig. 4. Character of development for the sedimentary cover over the geoblocks of the Pokrovo-Kireevo structure within the Near-Azovian region. Figure is composed by the author according to geological survey data from the Artemivsk prospecting expedition (V. A. Matiushonok, I.A. Maidanovich, 1970)

1 - Cainozoic sediments; 2 - Mesozoic poorly defined sediments; 3 - schists, sandstones, limestones of the Carboniferous age; 4 - Visean and Tournaisian sediments (limestones, schists); 5 - effusive-terrigenous stratum of the Upper Devonian, Razdolnenska suite; 6 - effusive-terrigenous stratum of the Upper Devonian, Dolhinska suite; 7 - effusiveterrigenous stratum of the Middl;e - Upper Devonian, Anton-Taramska suite; 8 - mafic dykes of the Precambrian; 9 - dykes of the Mesozoic age (andesites, andesite porphyrites, etc.); 10 - geoblocks of the Precambrian basement; 11 - fault zones; 12 - wells

The analysis of the mapping Bouguer anomalies for the Near-Azovian megablock shows the Elanchik horst and Pokrovo-Kireevo structure, on the whole, coincides with gravity anomaly [Келеватов, Полуновский, 1986; Лебедев, Собакарь, 1961; Собакарь 1961]. The positive gravitation field occupies most structure and conforms to geoblock formation of the large Elanchik horst and smaller blocks flanking it. The Pokrovo-Kireevo gravity anomaly within the $+52 \mathrm{mGal}$ isoline borders is $280 \mathrm{~km}^{2}$ at the intensity of $+90 \mathrm{mGal}$ in its centre. To west the Pokrovo-Kireevo gravity anomaly decreases sharply, forming the gravity shoulder more $20 \mathrm{mGal}$ at the field gradient of $4 \mathrm{mGal} / \mathrm{km}$ [Лебедев, Собакарь, 1961; Майданович, 1968]. The shoulder length here is about $45 \mathrm{~km}$ stretching along the large fault. This shoulder is connected by the geophysicists with the deep Kalmius fault zone, which passes from Shevchenko farm to Kolosky, Khleborob and other farms and further south west [Келеватов, Полуновский, 1986; Лебедев, Собакарь, 1961; Собакарь, 1961]. То east between the Hruzsky and Sukhoy Elanchik Rivers the intensity of the Pokrovo-Kireevo gravity anomaly is also changed by the value of $20 \mathrm{mGal}$ that results in the gradient of more $3 \mathrm{mGal} / \mathrm{km}$. In the most northern part of it approximately $11 \mathrm{~km}$ from the llovaisk - Taganrog Railway the gravity shoulder separates the Pokrovo-Kireevo maximum from the reduced part of field typical for the Donetsk fold structure. To south, the gravity shoulder of sublatitudinal trending separates the part of Pokrovo-Kireevo gravity maximum from the Telmanove one. The extent of shoulders here reaches to about $20 \mathrm{~km}$ and field gradients along them are more 20 eotvos [Собакарь, 1961].

Similarly, the changes of magnetic field take place within the Pokrovo-Kireevo structure. Their intensity decreases from the centre of the Elanchik horst to north, south, east and west. The magnetic anomaly for the area of structure is rather complicated owing to the existence of five epicenters [Келеватов, Полуновский, 1986]. Three western epicenters are drilled out by the numerous coring and exploratory wells. As a result it was distinguished three small massifs $(2 \times 3 \mathrm{~km})$ of Devonian pyroxenites and gabro-pyroxenites induced the mentioned magnetic anomalies. The distribu- 
tions of magnetic field and gravitation acceleration are characterized by the anomalous gradient zones of orthogonal and diagonal directions. They may be explained as the tectonic fault systems, which are associated with the magmatic bodies. These disjunctive forms create the framework for the fault intrusive structures being rooted in the magma producing origins. The electrical sounding for the area described identifies clearly the geoblock structure and subsidence of Precambrian mass from about $100 \mathrm{~m}$ depth at Kumachovka village (the former Pokrovo-Kireevo village) to the depth of $500 \mathrm{~m}$ to north of Ekaterinovka village [Майданович, 1968].

Essential information concerning the geoblock boundaries of the earth's crust for the
Pokrovo-Kireevo structure were obtained using remote sensing data and the analysis of geological and geophysical materials. It should be noted that aerospace survey data are earlier used rarely owing to the undercover area. Previously we have interpreted the largescale aerial photographs (1:17 000, 1:30 000), multiscale photographic sketches and satellite images in the scales of 1:500 000, 1:1 000000 , as well as some variants of morphometric and morphographic maps for this area. On a basis of the integrated map of the interpretation for aerospace and structural - geomorphological data the geological-structural map was compiled for the Pokrovo-Kireevo region. The block structures shown on this map (Fig. 5) and the rupture dislocations separated

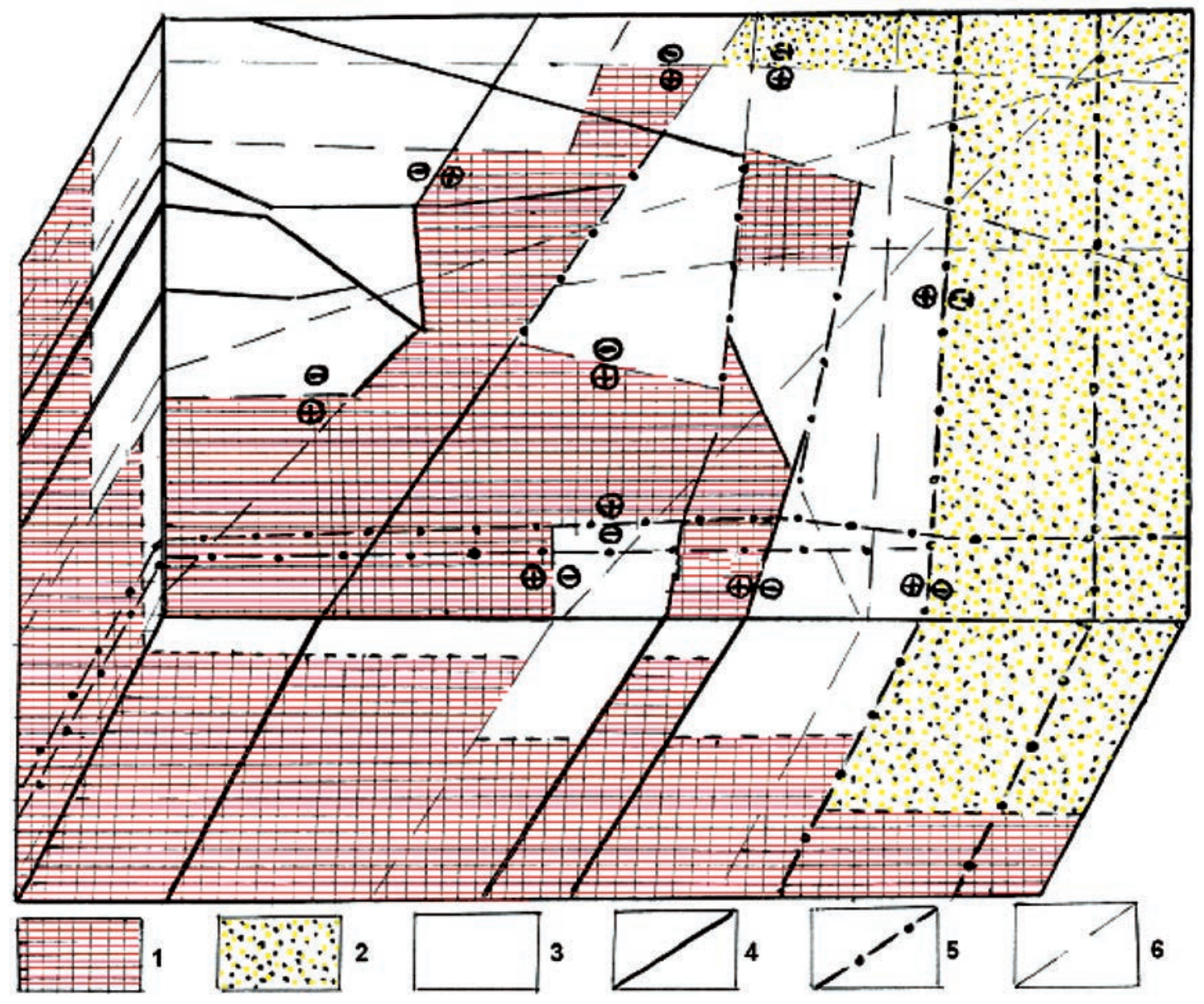

Fig. 5. Block-diagram of fault-block tectonics for the Pokrovo-Kireevo region using geological survey data. It is composed by the author using the materials from I.A. Maidanovich, V.A. Matiushonok, N.F. Rusakov, V.H. Verkhovtsev, 1970)

1 - upstanding blocks of the Pre-Riphean crystalline basement; 2 - downdip blocks of the basement; 3 - blocks occupying an intermediate position; 4 - faults distinguished by geological data; 5 - faults distinguished by geophysical data; 6 - faults distinguished by satellite images processing 
them often coincide with those earlier discovered using geological and geophysical data. However, the aerospace researches not only detail the locations of the known fault zones, but distinguish the new systems of lineaments and geoblocks, determine their interiors, which were proved by the following check boring. The aerospace survey data have identified the new faults in this region and especially their junctions, which are evidently perspective for the further prospecting endogenous mineralization within borders of the structural junction.

The analysis of geological and geophysical data and aerospace images show the Pokrovo-Kireevo ore cluster is controlled by the crossing the deep Southern Donetsk sublatitudinal fault with the Hruzsko-Elanchik submeridian fault zone, as well as the systems of rupture dislocations of the north-western and north-eastern trending. As a result, the studies have found that the Pokrovo-Kireevo structure in the whole presents the complicated horst - graben framework "keyboard pattern" (Fig. 1-5). In its borders some tectonic blocks were distinguished using aerospace, geological and geophysical data, as such the followings: to south-west the Elanchik horst, in the centre the PokrovoKireevo suture fault zone, to east the horst at the Kultura village and Pokrovo-Kireevo graben. The south-western Pokrovo-Kireevo region is most elevated and has two stages (Precambrian and Paleozoic). The region is separated into the small blocks of the different configurations by the systems of faults of submeridian, sublatitudinal and north-east trending (Fig. 5). The blocks are the small sizes consisting of the Precambrian and Phanerozoic volcano-sedimentary rocks of different ages and subsiding into the depth of $5 \mathrm{~m}$ to north and north-east directions. Faults divide here both the Precambrian and Paleozoic basement as well as the Meso-Cenozoic sedimentary mantle locally. The figures 1 and 5 show the fault zones of orthogonal orientation. In addition, the faults of north-east and north-west trending have played a significant role in the forming the small Paleozoic boss intrusion and dykes of ultrabasic, basic, and alkali-ultrabasic compositions, which occupied main volume of the ore district.

\section{Structure and morphology of the ore body}

On a basis of geological, geophysical, and aerospace studies as well as the drilling works it was found the features of structural position for the Pokrovo-Kireevo deposit, i.e. it is proved association of deposit with the junction between the sublatitudinal Southern Donetsk and submeridian Hruzsko-Elanchik deep faults. It was found that fluorite-rare-earth mineralization is confined to graben named then "ore" one. The "ore' graben area, where the fluorite-rare-earth deposit has been mapped, in turn, divided by the faults of orthogonal and diagonal systems into a number of smaller geoblocks. As the deposit is localized in graben, i.e. in a setting of Phanerozoic rocks and Precambrian basement geoblocks it is evident that fault-block tectonic movements caused the forming ore bodies of the deposit. Geological setting was also favorable for "intactness" of fluorite-rare-earth deposit from erosion in the following geological epochs. Two types of fluorite mineralization are revealed by the textural features and genesis of accumulation [Древин и др., 1960]. First type represents the hydrothermal zones of vein-disseminated, breccias ores among albitophyres, granites and other rocks, adjacent to the northwestern side of graben. Ore zone is tracked by the borehole profile along the extension to $4 \mathrm{~km}$ of length and $350 \mathrm{~m}$ and more of depth. The extension of zone is north-east (NE 20 $0^{\circ}$ ) and the dip is north-west, steep. Zone thickness is from 5 to $20 \mathrm{~m}$. The thickness of veinlet fluorite is varied from $1 \mathrm{~mm}$ to $5 \mathrm{~cm}$. Fluorite content in the zone is variable from 2 to $51 \%$ [Древин и др., 1960].

Second predominant type of deposit represents metosomatic occurrence of irregular shape among Carboniferous limestones from the Tournaisian stage. Fluorite occurrence is localized in the west corner of graben and confined to structure intersection node of the faults of NE- and NW-trending. It is controlled by NE fault and, in fact, parallel to the previous fluorite zone. The dip of ore - bearing zone is north-west here under the angle of $45-55^{\circ}$. Exploratory wells tracked the ore body along the extension to $100 \mathrm{~m}$ of length, and $80 \mathrm{~m}$ for a dip. The thickness of ore zone is varied from 8 to $80 \mathrm{~m}$. Fluorite content is variable from 20 to $85 \%$. The occurrence depth for the ore 
body of deposit is from 90 to 192 m [Древин и др., 1960].

Main minerals in ores from the PokrovoKireevo deposit are fluorite, calcite, dolomite, feldspar, and quartz. The secondary minerals are presented by siderite, barite, celestine, realgar, galena, sphalerite, and pyrite [Лазаренко и др., 1981; Панов и др., 1980]. Often fluorite is pseudomorphic replaced by other minerals such as quartz, calcite, etc. It is found in association with typical hydrothermal minerals, i.e. barite, sphalerite, galena, quartz, calcite, etc. According to mineral composition ores may be attributed to calcite-silicate-fluorite ones. In addition to fluorite mineralization at the Pokrovo-Kireevo deposit there are manifestations of native cooper, cinnabar, polymetals, and barite. It is important that the distribution of vein fluorite in the association with quartz, calcite, dolomite, lead- zinc and polymetal ores are rather often noted for the different fluorite deposits in the world. It is typical for metasomatic accumulations in sedimentary rocks.

In the prospecting pit fluorite is distinguished by the perfect cleavage through octahedron, vitreous luster, and cubic crystal habit. Color of fluorite $\left(\mathrm{CaF}_{2}\right)$ is predominantly purple, rarer there are colorless, white, yellow, blue, and green samples. Specific gravity is 3.2 , and refractive index is $1.425-1.43$. Dispersion is low; cleavage is perfect on $\{111\}$. lons of calcium in the fluorite structure are located according to face-centered cubic crystal, where every fluoride ion is positioned in the centre of the smaller cubes. The light samples of fluorite are low refraction. Low dispersion and isotropy for colorless fluorite minerals allow using them as good optical material. Samples with deep purple color have the high light refraction and low specific gravity. Fluorite color and its fluorescence are related to the distribution of crystallographic elements and physical disturbances of the crystal structures, impurities of radioactive and rare earth elements. Mineral is slightly soluble in $\mathrm{HCl}$ and dissolves completely in $\mathrm{H}_{2} \mathrm{SO}_{4}$. It is fusible and can be successfully applied in metallurgy as a flux. Fluorite may be synthesized also through evaporation of a solution of $\mathrm{CF}_{2}$ in $\mathrm{HCl}$.

Fluorites from the Pokrovo-Kireevo deposit, in particular, in the latest its generations arising from the productive mineralization stages consist of high content of rare earths and very high concentrations of strontium up to $1200 \mathrm{~g} / \mathrm{t}$ [Панов и др., 1980]. Strontium in fluorites from the Pokrovo-Kireevo deposit in total ratio is significantly higher than from the similar deposits of USA (to $100 \mathrm{~g} / \mathrm{t}$ ) and Germany (3-44 g/t). According to the German geologists the strontium concentrations in fluorites have being increased in the productivity stages of the Saxonic (Post-Variscan) mineragenic cycle. Therefore, strontium is important geochemical tracer of genetic affinity of fluorite with different stages of ore genesis. Contents of rubidium, scandium, cerium, lanthanum, europium, samarium, yttrium and other rare earth elements in Pokrovo-Kireevo fluorites vary within 1-8 $\mathrm{g} / \mathrm{t}$. The relationship between the color of minerals and rare earth content hasn't been established. For instance, green fluorite contains europium and samarium 3-4 times lower than purple sample. Therefore, these elements could not be considered as the chromophores for green color of fluorite than previously thought. It is here yttrium is distributed more contrast. Its decrease (to $1 \mathrm{~g} / \mathrm{t}$ ) was found in fluorspar of the latest generation. Fluorite from the different generations of the Pokrovo-Kireevo deposit is characterized by the high values of ratios $\mathrm{Ce}: \mathrm{Y}(0.5-1.5)$ and Ce : La (1.0-1.42). Similar cerium - lanthanum ratio (1.5-2.0) is observed for the productive mineralization stages for the commercial fluorite deposits of Thuringia and Saxony in Germany.

\section{Genesis}

By now, large amount of geological, mineralogical, and geochemical data are indicated that fluorine is key very informative chemical element. Owing to its wide abundance and migration mobility fluorine is key very informative chemical element. Owing to its wide abundance and migration mobility fluorine participates in different natural geological processes. When considering the genetic interrelations of fluorine with the different types of deep magmatic rocks of this region it was found that their close relations are absent. Fluorine is amagmatic, it hasn't genetic relations with magmatism. Consequently, it needs assuming their structural and paragenetic connection only. Fluorine has come from the deep zones of asthenosphere and lithosphere along fault tectonic zones in the period of their magmatic 
activation as a degassing product from the deep parts of the Earth. It is considered that fluorine degassing occurred from the deeper levels than level of generations for all known igneous rocks of this region. Moreover, fluorine degassing could arise both synchronously with volcanic processes and without the link with them. The latter is evident by the wide extension of fluoride mineralization both in the Donbas and within the whole of Near-Azovian Precambrian megablock of the USh. It is assumed that fluoride was deposited in the subsurface lithosphere horizons at the rather lower temperature. Fluorite mineralization in the region is everywhere confined to the large structural junctions of deep fault zones. In the Precambrian and Phanerozoic they served the favorable ore concentrating structures for fluorine, mercury, gold, rare metals and rare earth elements.

The "fluorine - mercury" breath of the Earth has been arisen just in the large junctions of tectonic fault zones. According to B.S. Panov etc. [Панов и др., 1980; Панов, Панов, 2000] there are ore agglomerates (realgar, cinnabar, stibnite ant others) of colloform texture in the Pokrovo-Kireevo deposit, that would suggest the involvement of colloid solutions in their formation. Sulfur isotopic composition of realgar indicates its similarity to cinnabar and stibnite from the productivity stages of mineralization. Sulfur isotopic composition of marcasite is characterized by increased content of "light" sulfur that proves the activity of sulfide sulfur from ore-hosting rocks in the final stage of hydrothermal process. This genetic feature of mineral formation in the Pokrovo-Kireevo structure was caused by relatively low external pressure under the moderate deep and subsurface conditions [Панов, Панов, 2000]. Above mentioned data show that the formation of Pokrovo-Kireevo fluorite - rare earth deposit is connected with the hydrothermal activity of solutions induced the metasomatic replacement of Carboniferous limestones [Древин и др., 1960].

\section{Age}

Time of intruding "fluorine" fluids and formation of the Pokrovo-Kireevo deposit is determined using geological, structural and isotopic data. Fluids have being penetrated through the Precambrian rocks and stratum of the Devon- ian volcanogenic sediments. The deposit is localized in limestones from the Tournai stage and overlapped by strata of the Jurassic, Cretaceous - Paleogene, and Quaternary rocks. B.S. Panov [Панов и др., 1980; Панов, Панов, 2000] connects mineralization with the Variscan orogeny. Isotopic age acquired previously for alkali rocks (malignites, aegirine pegamtites) of the Pokrovo-Kireevo structure varies in the range of 270-280 Ma. The other geo-chronological data produce the age of ore formation of the deposit in about 330-300 Ma.

\section{Conclusions}

Above data show that the faults of orthogonal and diagonal systems broke up the terrain of the south-eastern Ukraine into a number of small wedge-shaped geoblocks due to it was formed the sites with the highest fragmentation and the permeability of the lithosphere favorable for localization of ore substance within the Pokrovo-Kireevo structure. As a result of activation of should be smaller Pokrovo-Kireevo ore cluster and unique fluorine-rare earth deposit was formed. Above mentioned features for tectonomagmatic and metasomatic processes (depth, multistage, duration, intensity) and fragmentation of earth crust provoked by them as well as the deep differentiation of matter from the bowels of planet have been important in the formation of commercial concentrations of rare earths and fluorite within the ore cluster. Just these factors have provoked the appearance of mineralization under the conditions of crossing zones of the deep faults, where occurred the long evolution of tectonomagmatic and metasomatic processes both at the great depths and subsurface parts of the lithosphere. The Pokrovo-Kireevo ore cluster should be attributed to the category with the unique parameters of petrology and mineralization, such as high local concentrations of fluorite and rare elements and rather simple mineral composition of ore.

The South-Donetsk, Hruzsko-Elanchik and other deep faults, which caused the complicated horst - graben framework for the described Pokrovo-Kireevo structure were the degassing paths for fluorine and mercury from the depths of the Earth, generating so-called "fluorine - mercury" breathing. The rise of orebearing fluids originated predominantly in much "crushed" tectonic junctions, beyond 
magmatism. Forming the Pokrovo-Kireevo fluorite-rare earth deposit has occurred about $300 \mathrm{Ma}$ in the very complicated structural junction of described faults of the orthogonal and diagonal systems. The geological and structural conditions of its localization have arisen due to the processes of deep tectonic genesis, the hydrothermal activity of solutions caused by metasomatic replacement of the Carboniferous limestones. Ore deposit formation, probably, was predetermined by the energetic potential of the deep astenoliths, tectonics and

\section{References}

1. Бондарчук В.Г. Тектоника Большого Донбасса и происхождение ровообразных прогибов в платформе. Геол. журн. 1966. № 2 (107). C. 3-11.

Bondarchuk V,H., 1966. Tectonics of the Great Donbas and genesis of the trench - like depressions in the platform. Geologicheskij Zhurnal, vol. 26, № 2 (107), p. 3-11 (in Russian).

2. Бутурлинов Н.В., Скаржинский В.И. О комплексах магматических пород и магматических формациях Донецкого бассейна. Докл. АН ССCP. 1970. Т. 193, № 2. С. 401-404.

Buturlinov N.V., Skarzhynsky V.I., 1970. On the magmatic rock complexes and magmatic formations of the Donets Basin. Doklady AN SSSR, vol. 193, № 2, p. 401-404 (in Russian).

3. Быстревская С.С., Шаталов Н.Н. Глубинная структура земной коры по космическим изображениям (на примере Восточного Приазовья). Исследование Земли из космоса. 1980. № 5. C. 10-16.

Bystrevskaia S.S., Shatalov N.N., 1980. Abyssal earth crust structure from space images: Case of the eastern Near-Azovian area. Issledovaniy Zemli iz Kosmosa, № 5, p. 10-16 (in Russian).

4. Древин А.Я., Зарицкий А.И., Царовский И.Д. О строении юго-восточной краевой части Украинского щита (Покрово-Киреевская структура). Сов. геология. 1960. № 10. С. 137-140.

Drevin A.J., Zavaritsky A.N., Zarovsky I.D., 1960. On the structure of south-eastern marginal part of the Ukrainian Shield. Sovetskaya geologya, № 10, p. 137-140 (in Russian).

5. Келеватов Г.М., Полуновский Р.М. Некоторые вопросы тектоники и магматизма ПокровоКиреевской структуры и Грузско-Еланчикской зоны глубинных разломов. Геол. журн. 1986. № 3 (228). C. 97-103.

Kolevatov G.M., Polunovsky R.M., 1986. Certain Problems on Tectonics and Magmatism of the geological evolution history for the whole region, in particular, initiation and development of the Dono-Dnieper trough and a junction zone between the Donbas and Near-Azovian megablock of the USh. The deposit is localized in graben, which is later called as "mining one". The fast accumulation of the Meso-Cenozoic sedimentary strata in there has served as "a cover". It has kept the unique fluorite-rare earth occurrence of the Pokrovo-Kireevo deposit from erosion.

Pokrovo-Kireevan Structure and Gruzsky-Elanchik Zone of Deep Faults. Geologicheskiy Zhurnal, vol. 46, № 3 (228), p. 97-103 (in Russian).

6. Лазаренко Е.К., Лавриненко Л.Ф., Бучинская Н.И. Минералогия Приазовья. Киев: Наукова думка, 1981. 432 с.

Lazarenko Ye.K., LavrinenkoL.F., Buchinskaia N.I., 1981. Minerology of the Near-Azovian area. Kiev: Naukova Dumka, 432 p. (in Russian).

7. Лебедев Т.C., Собакарь Г.Т. Тектоника северо-восточного Приазовья по данным геофизических исследований. Докл. АН УССР. 1961. № 10. С. 564-567.

Lebedev T.S., Sobokar H.T., 1961. Tectonics of the north-eastern Near-Azovian area using geophysical data. Doklady AN USSR, № 10, p. 564-567 (in Russian).

8. Майданович И.А. О глубинной тектонике Донбасса. Докл. АН УССР. 1968. № 6. С. 506509.

Maidanovich I.A., 1968. On abyssal tectonics of the Donbas. Doklady AN USSR, № 6, p. 506-509 (in Russian).

9. Панов Б.С., Стремовский А.М., Бастьен Ж.Л. Редкоземельные и редкие элементы в флюоритах Донбасса и Призовья. Докл. АН УССР. Сер. Б. 1980. № 2. С. 29-32.

Panov B.S., Stremovsky A.M., Bastien Zh. L., 1980. Rare earth and rare elements in fluorspars from the Donbas and Near-Azovian area. Doklady AN USSR. Ser. B, № 2, p. 29-32 (in Russian).

10. Панов Б.С., Панов Ю.Б. Рудные формации Приазовской редкоземельно-редкометалльной области Украинского щита. Минерал. журн. 2000. № 1. С. 81-85.

Panov B.S., Panov Yu.B., 2000. The ore formations of the Near-Azovian rare earth - rare metal range of the Ukrainian Shield. Mineralogicheskiy Zhurnal, № 1, p. 81-85 (in Russian). 
11. Собакарь Г.Т. Структура зоны сочленения Донбасса с Приазовским массивом. Геол. журн. 1961. № 3 (78). С. 60-64.

Sobokar H.T., 1961. The structure of the conjunction zone of the Donbas with the Near-Azovian massif. Geologicheskiy Zhurnal, vol. 21, № 3 (78), p. 60-65 (in Russian).

12. Чебаненко И.И., Знаменская Т.А., Шаталов Н.Н. Проявление сдвиговой тектоники в структуре литосферы Украины. В кн.: Сдвиговые тектонические нарушения и их роль в образовании месторождений полезных ископаемых. Москва: Наука, 1991. С. 85-92.

Chebanenko I.I., Znamenskaia T.A., Shatalov N.N., 1991. Manifestation of fault tectonics in the lithosphere structure of Ukraine. In: Fault tectonic dislocations and their role in the mineral deposit formation. Moscow: Nauka, p. 85-92 (in Russian).

13. Шаталов Н.Н. Петрохимические особенности грорудитов Кузнецово-Михайловской зоны Приазовья. Докл. АН УССР. Сер. Б. 1981. № 8. C. 32-35.

Shatalov N.N., 1981. Petrochemical features of grorudites from the Kuznetsovo-Mikhailovsk zone of the Near-Azovian. Doklady AN USSR. Ser. B, № 8, p. $32-35$ (in Russian).

14. Шаталов Н.Н. Дайки Приазовья. Киев: Наукова думка, 1986. 192 с.

Shatalov N.N., 1986. The Near-Azovian dykes. Kiev: Naukova Dumka, 192 p. (in Russian).

15. Шаталов Н.Н., Верховцев В.Г., Русаков Н.Ф. Использование аэрокосмической информации при крупномасштабном геологическом картировании (на примере Покрово-Киреевского рудного района). В кн.: Применение аэрокосмической информации в геологии и смежных областях. Москва: Наука, 1987. С. 56-57.

Shatalov N.N., Verhovzev V.G., Rusakov N.F., 1987. Using aerospace information in large-scale geological mapping (on example of PokrovoKireevo ore district). In: Application of space information in geology and related fields. Moscow: Nauka, p. 56-57 (in Russian).

Received August 3, 2015 